\title{
İlk Yardım Eğitiminde Yaratıcı Drama Yönteminin Başarı Üzerine Etkisi
}

\author{
Behire SANÇAR* İnci AÇIKGÖZ ${ }^{* *}$ Ayşe Saba YALÇIN**
}

Ankara Üniversitesi

\begin{abstract}
$\ddot{O}_{z e t}$
Çalışma, ilk yardım dersinde kırılar ve elektrik çarpmaları konularında yaratıcı drama yönteminin etkisini belirlemek amacılla, Temmuz-Ağustos 2009 tarihleri arasında Ankara'da özel bir güvenlik kursunda ilk yardım eğitimi alan 100 kişi ile yapılmıştır. Eğitim, deney grubuna yaratıcı drama, kontrol grubuna ise geleneksel eğitimle verilmiştir. Çalışma için hazırlanmış olan anket, gruplara öntest ve sontest olarak araştırmanın başında ve sonunda uygulanmıştır. Elde edilen bulgulara göre, öntest-sontest puanları bakımindan deney ve kontrol gruplarl arasinda deney grubu lehine anlamlı farklılık bulunmuştur. Bu sonuç deney grubuna yaratıcı drama yöntemi ile verilen ilk yardım eğitiminin, ögrenenler üzerinde daha etkili olduğunu göstermektedir.
\end{abstract}

Anahtar Sözcükler: Yaratıcı drama, ilk yardım, güvenlik eğitimi, başarı

\begin{abstract}
This performance, was actualized about the fractures, and electric shock first aid subjects in order to determine the effects of creative drama method, between in July and August 2009 in Ankara in a special security area of first aid training course with 100 people. Creative drama education was given to the experimental group and traditional education was given to the control group. The questionnaire which was put into practise to the groups was carried out as a pretest and posttest at the beginning and the end of the reasearch.

According to the findings, in terms of pretest-posttest scores in favor of the experimental and control groups, significant differences were found between the experimental group. This result is given in the experimental group by using creative drama in education of the first aid, shows that it is more effective on learners.
\end{abstract}

Keywords: Creative drama, first Aid, safety education, success

\section{Giriş}

Yaratıcı drama, çocukların spontan oyunlarında ortaya çıkan, katılımcıların sanatsal duyarlılı̆̆ını, kendisi, başka insanlar ve dünya hakkındaki bilincini arttıran ve hayal gücünü geliştiren bir öğrenme aracidir (Pinciotti, 1993, s. 1).

Yaratıcı drama, doğaçlama ve rol oymana gibi tiyatro ve yaratıcı drama tekniklerinden yararlanılarak, bir grup çalışması içinde katılımcıların bir yaşantıyı, olayı, fikri, eğitim ünitesini, sosyal bir kavramı, davranışı, eski bilişsel örüntünün yeniden düzenlenmesi yoluyla gözlem, deneyim, duygu ve yaşantıların gözden geçirildiği oyunsu süreçlerde canlandırılmasıdır (San, 1996, s. 149).

(") Dr., Ankara Üniversitesi, Sağllk Bilimleri Fakültesi, (Yarı Zamanll).E-posta: bsancar@hotmail.com

$\left(^{* *}\right)$ Dr., Ankara Üniversitesi, Sağllk Bilimleri Fakültesi, E-posta: acikgoz@science.ankara.edu.tr

$\left(^{* *}\right)$ Dr., Ankara Üniversitesi, Sağllk Bilimleri Fakültesi, E-posta: syalcin@health.ankara.edu.tr 
Türkiye'de eğitimde yaratıcı dramanın 1980'lerden sonraki gelişimi yaratıcı dramanın doğduğu ve yaygın olduğu İngiltere, ABD, Kanada, Yeni Zelanda ve Almanya gibi ülkeler açısından bakıldığında önemli bir noktaya geldiği görülmektedir (Adıgüzel, 2008, s. 27). Yaratıcı drama, kavramı bazen bir yöntem, bazen bir alan, bazen de disiplin olarak karşımıza çıkmaktadır. Son yıllarda eğitim programlarında bir yöntem olarak daha çok kullanılmaktadır (Üstündağ, 1996, s. 20; 1998, s. 28).

Eğitimde yaratıcı drama, “önceden yazılmış bir metin olmaksızın, katılımcıların kendi yaratıcı buluşları, özgün düşünceleri, öznel anıları ve bilgilerine dayanarak oluşturdukları eylem durumları ve doğaçlama canlandırmalardır" şeklinde tanımlanabilir (San, 1997, s. 10). Eğitimde yaratıcı dramayı kullanmanın amaçları çocukların yaşına, içinde yaşanılan koşullara ve liderin hedeflerine göre değişir (Sağlam, 2004, s. 7). Yaratıcı drama kişiliğin gelişimini sağlar. Yaratıcı dramanın içeriği, fotoğraftan müziğe, heykelden şiire, öykü, eğitim, psikoloji, sosyoloji gibi pek çok alandan oluşabilmektedir. Yaratıcı drama, yaşantılara dayalı aktif, sosyal, tartışarak, keşfederek, duygusal etkileşim yoluyla öğrenmeyi sağlamaktadır.

Yaratıcı drama, çalışmalarına katılan bireyler, bu süreç içerisinde durumları, olayları, ilişkileri keşfederek, yaşayarak öğrenmektedirler. Bu yaşantıların kazanılması esnasında bireyin sözel ve sözel olmayan iletişim becerileri de gelişmektedir (Üstündağ, 2006, s. 27). Katılımcılar gerçek dünyadaki bilgi ve deneyimlerini yaratıcı dramada hayali bir dünya yaratmak için kullanmakta ve yaratıcı dramada tasarladıkları durumları ve rolleri tanımlarken olayları ve ilişkileri öğrenmektedirler (O’Neil ve Lambert, 1991, s. 11).

Yaratıcı drama, ortamında eğitimciler dünyayı anlayabilmeleri için çocukların ve ergenlerin kendileri ve çevreleriyle etkileşime girmelerini sağlamalıdır. Bu çalışmaların doğasında etkileşim vardır. Hem yaşamda hem oyunlarda temel yapıların benzer olması oyunun eğitimde kullanılmasına neden olmuştur. Yaratıcı drama, edilgenlik yerine katılımcı olma; bağımlılık yerine bağımsız olma ve karar verebilmenin yanı sıra yetkinleşme ve demokratikleşme niteliklerini kazandırmaya yardımcı olur. Yaratıcı drama esnasında katılımcılar yaratarak, geliştirerek, yansıtarak, kendilerini ve başkalarını tanımaktadırlar. Farklı görüşler ortaya koyarak, diğer kişilere karşı kişisel görüşlerini inceleyebilmektedirler. Bu davranış yaratıcı drama etkinliğine katılan katılımcıları tartışma ve çözüme götürmektedir (Fullford vd. 2001, s. 2).

Edwards ve Springate (1995, s. 25) yaratıcı drama etkinliklerinin çocuklukta yaratıcılığı ortaya koyma konusunda geniş olanaklar sunduğunu belirtmişlerdir.Yaratıcı dramada lider de önemlidir. Yaratıcı drama liderinin grup dinamiğini sağlama, bazı durumlarda zamanında müdahale ederek akışı değiştirme ve anında yeni durumlar yaratma gibi önemli nitelikleri bulunmaktadır.

\section{Yaratıcı Drama ve Yetişkin Eğitimi}

Yaratıcı drama çalışmaları, sanat eğitimi alanı başta olmak üzere eğitim bilimlerinin tüm alanlarından yararlanır. Çünkü yaratıcı drama, bireye yaratıcı ve eleştirel düşünme becerisi kazandırır. Birlikte çalışma alışkanlığı, sosyal gelişimi sağlama, kendine güven duyma ve karar verme becerileri, dil ve iletişim becerileri kazandırma, duygu ve düşüncelerini geliştirme hedefleri vardır. Bu becerileri yaratıcı drama sürecinde bireylerin yaratıcılıklarını kullanarak geliştirmeleri önemlidir (Önalan Akfırat, 2006, s. 
53). Sosyal beceriler olarak adlandırılan bu becerilerin çocuk ve ergenlerde olduğu kadar yetişkinlerde de geliştirilmesi gerekir.

Çocuk ve ergen eğitimde daha sık kullanılan yaratıcı drama yetişkin eğitiminde de kullanılmaktadır. Çocuk ve yetişkin eğitimindeki bazı kurallar birbirine benzemektedir. Bu iki eğitim yaklaşımını ve kurallarını bilmek ve yerinde kullanmak gerekir.

Yetişkin eğitiminde olumlu bir eğitim ortamı yaratmak için, katılımcıların beklenti ve gereksinimleri bilinmeli, katılımcılar da neden orada bulunduklarını anlamış olmalıdırlar.

Androgolojik yaklaşımda eğitimin dayandığı temel ilkeler:

1. En verimli öğrenme, katılımcı öğrenmeye hazır olduğunda gerçekleşir. Güdülenmeyi besleyecek ortamı sağlama.

2. Öğrenimi, katılımcıların bildikleri ya da deneyimleri üzerine yapılandırma.

3. Katılımcılara, neden öğrenmeleri gerektiği konusunda farkındalık yaratma.

4. Değişik eğitim teknikleri ve yöntemleri kullanma.

5. Beceri öğrenmek için gözlem altında ya da gerçeğe benzer ortamlarda (örn: oyunlaştırma ve maketler vb.) uygulama yapabilme.

6. Ortama ve gerçeğe yakın olduğu ölçüde eğitimde etkili olma.

7. Katılımcılara gelişimleri ile ilgili geribildirim verme.

Diğer tüm konularda olduğu gibi sağlıkla ilgili yeni bilgiler, tutumlar ve davranışlar edinmek üzere eğitimlere katılan yetişkinlerle çalışırken onların nasıl öğrendiği dikkate alınmalıdır. "Eğitim ve yetişme firsatlarından yararlanma konusunda karşılaşılan bazı eşitsizlikler (yaş, cinsiyet, toplumsal konum ve coğrafi köken vb.) yetişkin eğitimi yoluyla düzeltilmelidir. Bu anlamda sağlık eğitimi çalışmalarında kadınlara ve gençlere öncelik verilmelidir" (Ulusoy Gökkoca, 2001, s. 414).

\section{Sağlık Eğitiminde İlkyardım Eğitiminin Önemi}

Sağlık eğitimi, sağlığın korunması, geliştirilmesi, tedavi ve rehabilitasyonu konularında son derece önemlidir. Bireylerin, ailelerin, grupların, kuruluşların ve toplulukların ihtiyaç ve ilgileri sağlık eğitimi programlarının esas öğesini oluşturur. Sağlık eğitimi içinde ilkyardım eğitiminin önemi de göz ardı edilemeyecek kadar ciddi bir konudur.

İlk yardım, "herhangi bir kaza ya da yaşamı tehlikeye düşüren bir durumda sağlık görevlilerinin yardımı sağlanıncaya kadar, olay yerinde ve anında hayatın kurtarılması ve durumun kötüye gitmesini önlemek amacıyla ilaçsız olarak yapılan müdahaleler” şeklinde tanımlanabilir. Herhangi bir nedenle beyine kan gitmediğinde 4-6 dk. içinde beyin hücreleri hasar görmeye başlar. 6 . dakikadan sonra ise beyindeki hasar kaçınılmaz olduğundan ilk yardım müdahalesinin başlaması için saniyeler önem kazanır. İlk yardım, olay yerinde yapılması gereken bir uygulama olduğundan, anında orada bulunan kişiler tarafından yapılması gerekir (Nazik, 2003, s.7).

İlk yardım dersi kuramsal içeriğinin yanı sıra uygulama yönünün ağırlıkta olduğu bir derstir. Bu nedenle derslerde yaşayarak öğrenme için yaratıcı drama yönteminin kullanılması önemlidir.

Özellikle güvenlik görevlileri çalıştıkları alanlarda ilk yardım müdahalesi yapmak durumunda 
kalmaktadır. Bu nedenle güvenlik görevlilerinin uygulamalı ilk yardım eğitimini almaları ve öğrenme yaşantıları esnasında yaratıcı dramanın kullanılması yararlı olacaktır.

Nazik (1997, s. 122) çalışmasında, 0-6 yaş çocuğu olan 120 anne 3 grup halinde araştırmaya katılmış, bunlardan el kitabı verilenler 1 . sırada $(\% 17,5)$, yüz yüze eğitim yapılanlar 2 . sirada $(\% 12,5)$ kontrol grubunda ise 3. sırada ve oldukça az düzeyde $(\% 2,5)$ annenin 70 ve üzerinde toplam ilkyardım puanı aldıkları saptanmıştır. Bu çalışma eğitim materyali kullanmanın öğrenme üzerinde etkin rol oynadığının bir göstergesi olarak değerlendirilebilir.

Bebeklik ve çocukluk çağında meydana gelen düşme olaylarının büyük çoğunluğu ev ortamında oluşmakta ve yaş ilerledikçe çocuğun hareketlenmeye başlaması ile merdivenlerden düşmeler görülmektedir. Düşmeler sonrası vücudun çeşitli yerlerinde kırıklar görülebilmektedir.

Kırıklar ve elektrik çarpmaları evde, iş yerinde, okulda, sokakta ve başka birçok ortamda meydana gelebilmesi bakımından oldukça yaygın görülen yaralanma türlerindendir. Kırıklar ve elektrik çarpmalarında olay yerinde yapılacak ilk yardım müdahalesi hayat kurtarma ve kötüleşmeyi önlemesi açısından son derece önemlidir. Bu nedenle ilk yardım uygulamalarının herkes tarafindan bilinmesi ve hemen anında zaman kaybetmeden yapılması gerekmektedir. Kırıklar ve elektrik çarpmalarında yapılması ve yapılmaması gereken uygulamalar şöyle sıralanabilir:

\section{Kırıklarda İlk Yardım:}

Kırık, herhangi bir nedenle kemik bütünlügüünü bozulması olarak tanımlanmakta ve şiddetli darbelerin oluştuğu yaralanmalarda sıklıkla meydana gelebilmektedir. Kırık şüphesi varsa;

-Kırık bölgesi hareketsiz hale getirilir (tespit edilir).

-Kırığ 1 tespit etmek için atel adı verilen sert ve düz nesneler kullanılır.

-Kırık kemiğin alt ve üstündeki eklemi de içine alacak uzunluktaki ateller, bölgenin iç ve dış kısmından kan dolaşımını engellemeyecek şekilde bağlanır.

-Kalça ve bacak kırıklarında, iki ayak bileği birbirine sekiz sargı ile bağlanır.

-Kırık bölge soğuk tutulurken, şoku önlemek amacıyla tüm vücut sıcak tutulur.

-Kırık bölgenin altıdaki nabız, deri rengi ve 1sısı sık aralıklarla kontrol edilir.

-Hasta/yaralı sağlık kuruluşuna gönderilir ( Süzen, 2008, s. 128-29).

\section{Elektrik Çarpmalarında İlk Yardım:}

Elektrik çarpması, elektrik akımı ile temas sonucu meydana gelen ve vücutta yanıkların oluştuğu karışık bir şok durumdur.

-Öncelikle kişi akımdan kurtarılır.

-Elektrik akımı ana kaynağından kesilir.

-Hasta/Yaralının yaşamsal bulguları kontrol edilir (bilinç, hava yolu açıklığı, solunum ve dolaşım kontrolü).

-Yanık oluştu ise soğuk uygulama yapılır ve yanık yarasının hava ile teması kesilir.

-Yanan kişi sıcak tutulur ve hareket ettirilmez (Süzen, 2008, s. 157).

-Elektrik çarpan kişi çıplak elle tutulmaz, elektrik geçirmeyen bir cisimle kablo itilir.

-Elektrik çarpmasında ise yere sert bir şekilde düşme, çarpma ve kasılmalar sonucu kırıklar 
oluşabilmektedir. Bu durumda kırıktaki ilk yardım müdahaleleri aynen uygulanır. Ayrıca elektrik çarpmasının kalp üzerine etkisi de vardır. Kalp durması varsa, kalp masajı yapılır. Bölgesel yanıklara da diğer yanık yaralarındaki gibi müdahale edilir.

Kazalar ve yaşamı tehlikeye düşüren durumlarla ilgili önlemler alınması kadar bu durumlar meydana geldikten sonra yapılacakları bilmek ve uygulamak da çok önemlidir. Bu nedenle toplumun tüm kesimlerine kalıcı izli eğitimler verilmesi gerekir. Bu tür eğitimlerde yaşayarak öğrenmenin önemi büyüktür. Bu konuda yaratıcı drama yönteminin kullanılması yararlıdır. İlkyardım eğitimlerinde halen kullanılmakta olan eğitim yöntemlerinin yanı sıra yaratıcı drama yöntemiyle eğitim de kullanılmaktadır. Ancak alan yazında bu yöntemin ilkyardım eğitimindeki etkisini değerlendiren herhangi bir çalışmaya rastlanmamıştır. Grup süreçleriyle öğrenmenin eğitimdeki öneminin anlaşılması nedeniyle tüm derslerde bu yönteme gereksinim vardır. Sosyal becerilerin gelişimi ve kendini ifade bakımından önemli olan bu yöntemin ilkyardım dersinde kullanılmasının öneminden yola çıkarak bu çalışma planlanmıştır.

Yaratıcı drama yönteminin ilk yardım eğitimi üzerindeki etkisinin belirlenmesi amacıyla yapılan çalışmada şu alt hedefler bulunmaktadır:

1. Kırıklar ve elektrik çarpması durumunda katılımcıların yaptıkları ilk yardım uygulamalarını belirleme.

2. Katılımcıların ilk yardım konusundaki bilgileri ve uygulamalarını öğrendikleri kaynakları tespit etme.

3. Yaratıcı drama ve anlatım yöntemlerinin ilk yardım eğitimindeki etkinliğini belirleme.

Araştırmada elde edilen sonuçların, kazalar sonucu meydana gelen kırıklar ve elektrik çarpmaları konusunda kişilerin bilinçlendirilmesine yardım edeceği, bu konularda verilecek ilk yardım eğitimlerinin yöntemine karar vermede katkı sağlayacağı ve yapılacak diğer araştırmalara örnek teşkil edeceği düşünülmektedir.

\section{Yöntem}

Çalışma, yaratıcı drama yönteminin, ilk yardım eğitimindeki etkisini belirlemek amacıyla planlanmış ve özel bir güvenlik kursunda gerekli izin alınarak uygulanmıştır. Araştırmada öntest-sontest kontrol gruplu deneysel model kullanılmıştır.

\section{Örneklem}

Araştırmaya, Temmuz-Ağustos 2009 tarihleri arasında Ankara'da özel bir güvenlik kursuna devam eden ve ilk yardım dersi alan 100 katılımcının tamamı katılmıştır.

\section{İșlem}

Veriler, İlk Yardım Eğitici Sertifikası'na sahip olan ve ilk yardım eğitimleri veren Sançar tarafından hazırlanan 9 soru demografik özellikler, 15 soru kırıklar, 10 soru elektrik çarpmaları konularıyla ilgili olmak üzere toplam 34 sorudan oluşan "yaratıcı drama yönteminin ilk yardım eğitimindeki etkisinin araştırılması" isimli anket formuyla toplanmıştır. Anketteki, 12 soru boşluk doldurma, 13 soru Doğru (D), Yanlış (Y) biçiminde olmak üzere katılımcıların sorulara verdiği yanıtlar Doğru ise "1", Yanlış ise “ 0 ” olarak puanlandırılmıştır. Anketten alınabilecek en yüksek puan 25'dir. Anketin kapsam geçerliliği için uzman hemşire (3), uzman psikolog (1), istatistik uzmanı (1), program geliştirme uzmanı (1) ve 
ilk yardım eğiticisi (1) olmak üzere toplam 7 uzman görüşlerine başvurulmuştur. Uzman görüşleri doğrultusunda, önerilerle geçerliliği belirlenerek düzenlenmiştir. Güvenirlik için hem kontrol grubunun ön-son test puan ortalamaları arasındaki ilişki pearson korelasyon testi ile değerlendirilmiş, hem de cronbach alfa iç tutarlılık katsayısı hesaplanmıştır. Her iki durumda da $\mathrm{r}=0.76$ bulunmuştur. Bu sonuç, anketin oldukça güvenilir olduğunu göstermektedir. (Tavşancıl, 2006, s.29).

Katılımcılar deney ve kontrol grubu olmak üzere rastgele iki gruba ayrılmıştır. Gruplardaki katılımcı sayısı birbirine denktir. Anket her iki gruba da kursun başlangıcında ilk yardım dersi verilmeden önce uygulanmıştır. İlk yardım dersi deney grubuna yaratıcı drama yöntemi kullanılarak, kontrol grubuna ise geleneksel eğitim ile her iki gruba da aynı araştırmacı tarafından verilmiştir. Bu yöntemle ders işlenen grupta dersler geleneksel öğrenme yaşantılarıyla sürdürülmüş, öğrenci aktif olarak derse katılmamıştır.

Yaratıcı drama yönteminde ise eğitim etkinliği 3 aşamadan oluşmuştur:

1. Hazırlık- Isınma. 2. Canlandırma. 3. Değerlendirme.

Hazırlık aşamasında katılımcılara eğitimin konusu açıklanmıştır. Kırıklar ve elektrik çarpmaları ile ilgili daha önceki yaşantılarından örnekler anlatmaları istenmiştir. Bu durumlarda ne gibi ilk yardım uygulamaları yaptıklarını hatırlamaları ve ne yapmaları gerektiği konusunda yeni fikirlerini de ortaya koymaları söylenmiştir. Bu bölümde katılımcılar, lider ve mekân arasındaki iletişim süreci başlatılmıştır. Canlandırma aşamasında bir iş kazası ortamı yaratılarak katılımcılar kırı̆̆ı olan ve elektrik çarpması olan kişilere ilk yardım uygulaması yapmışlardır. Değerlendirme aşamasında ise katılımcıların duygu ve düşüncelerini grup ile paylaşmaları sağlanmış ve eğitsel kazanımları tartışılarak pekiştirilmiştir. Yaratıcı drama ile öğrenilenleri gelecek yaşantılarında etkili olup olmayacağı tartışılmıştır (Adıgüzel, 2006, s. 26). Kursun sonunda ilk yardım dersinde katılımcılara aynı anket yeniden uygulanmıştır. Böylece ilk yardım dersi almadan önce ve sonrasında deney ve kontrol gruplarına aynı anket ön-son test olarak uygulanmıştır. İlk yardım dersi öğrenim yaşantıları esnasında geleneksel ve yaratıcı drama yöntemi kullanımının grupların başarıları arasında bir farklılık oluşturup oluşturmadığı belirlenmeye çalışılmıştır.

Verilerin değerlendirilmesinde, tanımlayıcı istatistik, bağımsız gruplarda t-testi, tek değişkenli kovaryans analizi (ANCOVA), ki-kare testi SPSS programı kullanılarak yapılmıştır.

\section{Bulgular}

Yaratıcı drama yönteminin ilk yardım eğitimindeki etkisinin araştırılması isimli, 34 sorudan meydana gelen ölçme aracı deney ve kontrol gruplarına eğitim öncesi öntest olarak uygulanmıştır. Elde edilen bu bulgulara göre, ilk yardım eğitimine katılanların yaş aralığı 18 ile 47 arasında olmak üzere, yaş


her iki grupta da erkekler oluşturmaktadır. Deney grubundakilerin \%74'ü, kontrol grubundakilerin \%80'i erkektir. Mezuniyet durumuna bakıldığında çoğunluğun lise mezunu olduğu, bunu ortaokul mezunlarının izlediği görülmektedir. Deney grubundakilerin \%52'si lise, \%32'si ortaokul; kontrol grubundakilerin \%64'ü lise, \%32'si ortaokul mezunudur.

Deney grubundakilerin \%62'si ( $n=31)$, kontrol grubundakilerin \%74'ü $(n=37)$ daha önce ilk yardım eğitimi aldıklarını belirtmişlerdir. Eğitimi, deney grubundakilerin \%33.90’1 (n=20) sürücü kursundan, 
\%16.95'i (n=10) okuldan, \%10.17'si (n=6) askerlikte, \%5.08'i (n=3) ilk yardım kursundan, \%33.90'1 $(n=20)$ diğer; kontrol grubundakilerin \%38.46's1 (n=25) sürücü kursundan, \%24.61'i (n=16) askerlikte, $\% 12.31$ 'i $(n=8)$ okuldan, \%3.08'i $(n=2)$ ilk yardım kursundan, \%21.54'ü $(n=14)$ diğer yerlerden aldıklarını ifade etmişlerdir.

İlk yardım konusunda bilgiyi, deney grubundakilerin \%26.56's1 ( $\mathrm{n}=17)$ televizyon, radyo, internetten; \%21.88'i (n=14) öğretmenden, \%7.81'i $(n=5)$ doktordan, \%17.19’u (n=11) diğer yerlerden öğrendiği; \%18.75'inin ( $\mathrm{n}=12)$ bu konuda önceden bilgisinin olmadığ 1 görülmüştür. Kontrol grubundakilerin ise, \%22.58'i (n=14) öğretmenden; \%19.35'i $(n=12) \quad$ televizyon, radyo, internetten; \%17.74'ü ( $\mathrm{n}=11)$ doktordan; \%11.29'u (n=7) kitap, dergi, gazetelerden; \%14.52'si (n=9) diğer yerlerden öğrendiği; \%14.52'sinin (n=9) ilk yardım konusunda daha önceden bilgisinin olmadığı saptanmıştır (Tablo 1).

Tablo 1. İlk Yardım Ĕgitimine Katılanların Demografik Ve İlk Yardım Eğitim Durumlarının Dă̆glımları

\begin{tabular}{|c|c|c|c|c|}
\hline & \multicolumn{2}{|c|}{ Deney } & \multicolumn{2}{|c|}{ Kontrol } \\
\hline & Sayı & $\%$ & Sayı & $\%$ \\
\hline Yaş & & & & \\
\hline $18-27$ & 40 & 80.00 & 33 & 66.00 \\
\hline $28-37$ & 4 & 8.00 & 14 & 28.00 \\
\hline $38-47$ & 6 & 12.00 & 3 & 6.00 \\
\hline Cinsiyet & & & & \\
\hline Erkek & 37 & 74.00 & 40 & 80.00 \\
\hline Kadın & 13 & 26.00 & 10 & 20.00 \\
\hline Medeni Durum & & & & \\
\hline Evli & 13 & 26.00 & 14 & 28.00 \\
\hline Bekar & 37 & 74.00 & 36 & 72.00 \\
\hline Çocuk & & & & \\
\hline Var & 8 & 16.00 & 11 & 22.00 \\
\hline Yok & 42 & 84.00 & 39 & 78.00 \\
\hline Meslek & & & & \\
\hline İşçi & 14 & 28.00 & 17 & 34.00 \\
\hline Memur & 7 & 14.00 & 5 & 10.00 \\
\hline Ev Hanımı & 2 & 4.00 & 2 & 4.00 \\
\hline Serbest & 6 & 12.00 & 12 & 24.00 \\
\hline İşsiz(boş) & 21 & 42.00 & 14 & 28.00 \\
\hline Mezun Olduğu Okul & & & & \\
\hline İlk & 1 & 2.00 & - & - \\
\hline Orta & 16 & 32.00 & 16 & 32.00 \\
\hline Lise & 26 & 52.00 & 32 & 64.00 \\
\hline Üniversite & 6 & 12.00 & 1 & 2.00 \\
\hline Diğer & 1 & 2.00 & 1 & 2.00 \\
\hline Daha önce Eğitim & & & & \\
\hline Almış & 31 & 62.00 & 37 & 74.00 \\
\hline Almamış & 19 & 38.00 & 13 & 26.00 \\
\hline
\end{tabular}




\begin{tabular}{|l|rrrr|}
\hline Eğitim Aldığı Yer & & & & \\
Sürücü kursu & 20 & 33.90 & 25 & 38.46 \\
İlk Yardım kursu & 3 & 5.08 & 2 & 3.08 \\
Askerlik & 6 & 10.17 & 16 & 24.61 \\
Okul & 10 & 16.95 & 8 & 12.31 \\
Diğer & 20 & 33.90 & 14 & 21.54 \\
\hline İlk yardım bilgisi & & & & \\
Bilgisi yok & 12 & 18.75 & 9 & 14.52 \\
Doktor & 5 & 7.81 & 11 & 17.74 \\
Öğretmen & 14 & 21.88 & 14 & 22.58 \\
Kitap & 5 & 7.81 & 7 & 11.29 \\
Tv, radyo, internet & 17 & 26.56 & 12 & 19.35 \\
Diğer & 11 & 17.19 & 9 & 14.52 \\
\hline
\end{tabular}

Gruplar arasında cinsiyet, mezun olduğu okul ve daha önce ilk yardım eğitimi alma bakımından anlamlı bir farklılık olmadığı $(\mathrm{p}>0.05)$, sadece yaş bakımından anlamlı bir farklılık olduğu $\mathrm{X}^{2}=7.227, \mathrm{sd}=2,(\mathrm{p}<0.05)$ belirlenmiştir. Grupların eğitim öncesinde kırıklar ve elektrik çarpmaları konusundaki ilk yardım bilgilerini belirlemek amacıyla uygulanan ölçme aracının öntest puan ortalamaları arasında bir farklı1ık olup olmadığı bağımsız gruplarda t testi ile karşılaştırılmıştır (Tablo 2).

Tablo 2. Deney ve Kontrol Grubunda Yer Alan Katılımciların Öntest

Puanları İçin Yapılan Bă̆ımsız Grup t Testi Sonuçları

\begin{tabular}{|lccccc|}
\hline Gruplar & $\mathrm{N}$ & $\bar{X}$ & $\mathrm{~S}$ & $\mathrm{t}$ & $\mathrm{p}$ \\
\hline Deney & 50 & 7.84 & 3.30 & & \\
Kontrol & 50 & 10.22 & 2.61 & & $\mathrm{p}<0.05$ \\
\hline
\end{tabular}

Tablo 2'de öntest puan ortalamaları bakımından deney ve kontrol grupları arasında anlamlı bir farklılık olduğu bulunmuştur ( $\mathrm{t}=-4, \mathrm{sd} .=98, \mathrm{p}<0.05)$. Katılımcıların öntest puan ortalamaları ( $\mathrm{X}_{\text {Deney }}$ $=.84 ., \mathrm{X}_{\text {kontrol }}=10.22$ ) incelendiğinde, bu farkın kontrol grubu lehine olduğu belirlenmiştir. Bu sonuca dayanarak deney ve kontrol grubunun öntest puanları bakımından benzer olmadığı görülmüştür. Grupların öntest ortalamaları arasındaki bu farkı ortadan kaldırabilmek için güçlü bir analiz olan tek değişkenli kovaryans analizi (ANCOVA) uygulanmıştır. Başka bir deyişle, deney ve kontrol gruplarının sontest ortalama puanları arasında farklılaşma olup olmadığ 3, Tablo 4). Çalışmada, kovaryans analizinin kullanılması için gerekli olan varsayımların karşılanıp karşılanmadığı incelenmiş ve karşılandığı tespit edilmiştir (Büyüköztürk, 2007, s. 48).

Bazen denekler şans yoluyla gruplara rastgele atansa da ortalama öntest puanları arasındaki fark anlamlı çıkabilir. Öntest ortalamalarında ilk farklılıkları düzeltmede, kovaryans analizi kullanılabilir. $\mathrm{Bu}$ istatistiksel teknikle, ortalama değişme puanlarına ilk puanlardaki farklılıklardan ziyade deneysel işlemin etkisi olduğu yorumu gerçekleştirilebilir (Borg ve Gall, 2011, s. 138). 
ANCOVA, sadece potansiyel ortak bir değişkene ilişkin olarak gruplar arasında anlamlı farkların olması durumunda değil, ortak değişken ile bağımlı değişkene ait puanlar arasında doğrusal bir ilişkinin olması durumunda, başlangıçta grup ortalama puanlarının eşit olması koşulu altında dahi kullanılabilen güçlü bir istatistiktir (Büyüköztürk, 2010, s. 111).

Tablo 3. Deney ve Kontrol Grubunda Yer Alan Katılımclların Öntest-Sontest

\begin{tabular}{|c|c|c|c|c|c|c|}
\hline \multirow[t]{2}{*}{ Gruplar } & \multirow[t]{2}{*}{$\mathrm{N}$} & & \multicolumn{2}{|c|}{ Toplam puanlar } & \multicolumn{2}{|c|}{$\begin{array}{l}\text { Düzeltilmiş Son test } \\
\text { Puanları }\end{array}$} \\
\hline & & & $\bar{X}$ & $\mathrm{~S}$ & $\bar{X}_{d}$ & $\mathrm{SH}$ \\
\hline \multirow[t]{2}{*}{ Deney } & \multirow[t]{2}{*}{50} & Ön test & 7.84 & 3.30 & & \\
\hline & & Son test & 17.46 & 3.15 & 18.34 & 0.337 \\
\hline \multirow{2}{*}{ Kontrol } & \multirow{2}{*}{50} & Ön test & 10.22 & 2.61 & & \\
\hline & & Son test & 15.22 & 3.18 & 14.34 & 0.337 \\
\hline
\end{tabular}

Tablo 3'de görüldüğü gibi kovaryans analizi sonucunda; daha önce deney grubunun sontest puan ortalaması $\left(\mathrm{X}_{\text {Deney }}=17.46\right)$ iken düzeltilmiş sontest puan ortalaması $\left(\mathrm{X}_{\text {Deney }}=18.34\right)$ 'e yükselmiş; kontrol grubunun sontest puan ortalaması $\left(\mathrm{X}_{\text {Kontrol }}=15.22\right)$ iken düzeltilmiş son test puan ortalaması $\left(\mathrm{X}_{\text {Kontrol }}=14.34\right)$ 'e düşmüştür.

Tablo 4. Deney ve Kontrol Grubunda Yer Alan Katılımclların Öntest Puanlarına Göre Sontest Puanlarının Kovaryans Analizi Sonuçları

\begin{tabular}{|c|c|c|c|c|c|c|}
\hline $\begin{array}{l}\text { Varyansın } \\
\text { Kaynağ1 }\end{array}$ & $\mathrm{KT}$ & sd & $\mathrm{KO}$ & $\mathrm{F}$ & $\mathrm{p}$ & Eta-Kare \\
\hline Model & 596.619 & 2 & 298.309 & 56.757 & .000 & 0.539 \\
\hline Öntest(Reg.) & 253.755 & 1 & 253.755 & 48.280 & .000 & 0.332 \\
\hline Grup & 342.864 & 1 & 342.864 & 65.234 & .000 & 0.402 \\
\hline Hata & 509.821 & 97 & 5.256 & & & \\
\hline Toplam & 1106.440 & 99 & & & & \\
\hline
\end{tabular}

Tablo 4.'e göre, deney ve kontrol grubundaki katılımcıların öntest puanları kontrol altına alındığında, düzeltilmiş sontest puan ortalamaları arasındaki farkın anlamlı olduğu bulunmuştur $\left(\mathrm{F}_{1 ; 97}=65.234\right)$ (, p<0.05). Tablo 3'de görüldüğü gibi farkın deney grubu lehine olduğu düzeltilmiş ortalamalardan $\left(\mathrm{X}_{\text {Deney }}=18.34 ; \mathrm{X}_{\text {kontrol }}=14.34\right)$ anlaşılmaktadır. Bu bulguya dayanarak uygulanan deneysel işlemin (yaratıcı drama yönteminin) ilk yardım eğitimindeki başarıyı önemli ölçüde etkilediği söylenebilir. Sontest puanları için varılan sonucu eta-kare değeri de desteklemektedir. Grup için hesaplanan eta-kare 
değeri, etki büyüklüğünün yüksek olduğunu, farklı gruplarda olmanın, öntest puanlarından bağımsız olarak, sontest puanlarındaki değişkenliğin \%40,2'sini açıkladığını göstermektedir. Ayrıca öntest puanları son test puanları için önemli bir yordayıcıdır. $\left(\mathrm{F}_{(1 ; 97)}=48.20\right)$ ve tek başına sontest puanlarındaki değişimin \%33,2'sini açıklamaktadır. Kurulan model sontest puanlarındaki değişkenliğin \%53,9'unu açıklamaktadır ve bunu tanımlayan ANCOVA modelinin anlamlı olduğu görülmektedir $\left(\mathrm{F}_{(2 ; 97)}=56.757\right.$, $\mathrm{p}<0.05)$.

$\mathrm{Bu}$ sonuçlar deney grubuna yaratıcı drama yöntemi ile verilen ilk yardım eğitiminin daha etkili olduğunu göstermektedir.

\section{Tartışma ve Yorum}

Yaratıcı dramanın bir öğrenme yolu olarak en önemli varlığg zihinsel, sosyal ve psikomotor yeteneklerle bütünleşmiş olmasıdır. Bu öğrenme etkinliğinde, katılımcı diğerleriyle birlikte düşünür, hisseder ve hareket eder (Ömeroğlu, 1990, s. 25). Bu çalışmada yaratıcı drama yöntemi ile ilk yardım eğitimi alan katılımcılar, önceleri-çekingen ve sıkılgan davranmalarına rağmen, yaratıcı drama etkinliklerinin sonuna doğru kendilerine güvenlerinin arttığını diğerleriyle paylaşımın sosyalleşme açısından yararlı olduğunu belirtmişlerdir.

Tekerek (2007, s. 190) çalışmasında, yaratıcı drama etkinliklerinin, amacı doğrultusunda daha verimli olabilmesi için kişinin enerjisini ve yaratıcılığını açığa çıkararak uzman, donanımlı ve yaratıcı liderler eşliğinde, uygun mekânlarda, karşılıklı güven, içtenlik ve işbirliği içinde gerçekleştirilmesinin yararlı olacağını belirtmiştir. Çalışmada deney ve kontrol grubundaki katılımcıların öntest puanları kontrol altına alındığında, sontest puanları arasında deney grubu lehine istatistiksel olarak anlamlı bir fark bulunması, deney grubunda uygulanan yaratıcı drama yönteminin, kontrol gruplarına uygulanan geleneksel yönteme göre daha etkili olduğu görülmüştür. Bu çalışmanın bulguları, yaratıcı drama yönteminin farklı düzey ve konularda etkililiği üzerine yapılan diğer çalışmaların bulgularıyla benzerlik göstermekte, elde edilen sonuçları destekler niteliktedir:

Susar Kırmızı (2008, s. 108) çalışmasında, okuduğunu anlama stratejileri ölçeğinin tümüne ilişkin olarak, "Yaratıcı Drama Yöntemine Dayalı Öğrenme” ve "Türkçe Dersi Öğretim Programına Göre Öğrenme" grupları arasında deney grubu lehine önemli bir fark olduğu bulunmuştur.

Selvi (2003, s. 181-88) yaratıcı dramanın fen öğretimindeki etkisini incelediği çalışmasında bu yöntemin öğrenme-öğretme sürecinde öğrencinin zihinsel, duyuşsal ve devinişsel olarak aktif katılımına destek sağladığını göstermiştir.

Ayrıca, Çebi (2008, s. 573) çalışmasında, OMÜ Eğitim Fakültesinde "Yaratıcı Drama Destekli Bilgisayar Okuryazarlığı" kapsamında bazı ders tasarımları yaptıklarını ve bu tasarımları Samsun'da çeşitli ilköğretim okullarında küçük deneysel çalışmalara dönüştürüp, geleneksel ders tasarımlarıyla yapılan karşılaştırmalarda, yaratıcı drama destekli tasarımlar doğrultusunda oldukça anlamlı farklar ortaya çıktığını belirtmiştir.

Başka bir çalışmada (Üstündağ, 2008, s. 146) bireye; bir sorunla karşılaştığında ne yapacağını gösterme, bilgiye nasıl ulaşacağının yollarını deneme fırsatları verme, kendini dingin ya da denetim altında tutma ve hatta duygusal olarak rahatlama yaratıcı dramanın işgörüleri arasında gösterilmiştir. Aynı 
çalışmada Polislerin hizmet içi eğitimlerinde yaratıcı dramaya yer verildiği ve polis eğitiminde ya da meslek yaşamının içinde hem kendi bireysel birikimlerinden sürekli yararlanmak, hem de gerektiğinde bu birikimi "canlandırarak" başkalarıyla paylaşmanın kendiliğinden yer alabildiği belirtilmiştir. Bu çalışmada, meslek kazandırma eğitimlerinden biri olan güvenlik görevlisi yetiştirme kurslarında yaratıcı drama yönteminin uygulanmasının bu meslek grubunun eğitimine katkıda bulunduğu ileri sürülebilir.

Kara ve Çam, (2007, s. 155) tarafından yapılan bir başka çalışmada, yaratıcı drama yönteminin gelişim ve öğrenme dersinde sosyal becerilerden, grupla bir işi yapma ve yürütme becerileri, ilişkiyi başlatma ve sürdürme becerileri ile kendini kontrol etme becerilerinin gelişiminde önemli katkılar sağladığ belirtilmektedir.

Çam, Özkan, Avinç (2009) tarafından yapılan çalışmada drama yönteminin akademik başarı bakımından anlamlı olduğu, bu yöntemle derse olan ilginin arttığı ve öğrencilerin sevdikleri sonucu bulunmuştur. Bu sonuçlar, Fen ve Teknoloji alanında yapılan diğer çalışmalarla da uyumludur (Sağırlı, 2001; Bıyık, 2001; Baykent, 2002, Akoğuz, 2002; Oğur ve K1lıç, 2004; Doğan, 2004).

$\mathrm{Bu}$ çalışmada elde edilen bulgularla benzerlik göstermeyen, Sağırlı ve Gürdal (2002, s. 221) çalışmalarında fen bilgisi dersinde drama tekniğinin öğrenci başarısına etkisini incelemişler; eğitim sonrası kontrol ve deney grubunun son testleri arasında anlamlı bir farklılık bulamamışlardır.

Ayrıca, Nazik (1997, s. 59-66) 0-6 yaş çocuğu olan annelere verilen ev kazalarında ilk yardım eğitimi modellerini karşılaştırdığı çalışmasında, annelerin ev kazalarında ilk yardım uygulamalarını öğrendiği kaynakları incelemiştir. Annelerin kırıklar ve elektrik çarpmalarıyla ilgili ilk yardım uygulamalarını öğrendikleri kaynak olarak Tv ve radyo son sırada yer alırken, çalışmamızda katılımcıların deney grubunda \%26.56 ve kontrol grubunda \%19.35 ile ilk sırada tv radyo ve internetten öğrendikleri tespit edilmiştir. Sonucun farklı çıkmasında son yıllarda internete ulaşmadaki yaygınlığının etkisi olduğu söylenebilir.

Erdoğan (2006, s.49) çalışmasında, ilköğretim 8. Sınıf (14-15 yaş) öğrencilerinin depresif belirti ve öz kavram düzeylerine yaratıcı drama çalışmalarının etkisi incelenmiştir. Başlangıçta deney ve kontrol grubu arasında depresif belirti ve öz kavram seviyeleri arasında istatistiksel olarak anlamlı bir fark yok iken, yaratıcı drama eğitiminden sonra deney grubunda Çocuk Depresyon Ölçeği (ÇDÖ) puanlarının anlamlı olarak düştüğü ve Piers-Harris Çocuk Öz Kavram Ölçeği (PHÇÖKÖ) puanlarının anlamlı olarak yükseldiği, kontrol grubunda ise ön ve son test puanları arasında istatistiksel olarak anlamlı bir farklılığın olmadığı saptanmıştır. Bu bulgular da çalışmamızın bulgularıyla benzerlik göstermektedir.

\section{Sonuç ve Öneriler}

$\mathrm{Bu}$ araştırmada ilk yardım eğitiminde geleneksel eğitim ve yaratıcı drama yönteminin etkisi incelenmiştir. Deney ve kontrol gruplarının sontest puanlarının ortalamaları arasında anlamlı bir farklılık vardır. İlk yardım eğitimini yaratıcı drama yöntemi ile alan katılımcıların (deney grubunun) son test puanlarının, dersi geleneksel yöntemle alan katılımcıların (kontrol grubunun) sontest puanlarından daha yüksek olduğu bulunmuştur. Bu bulgular doğrultusunda ilk yardım eğitimine yaratıcı drama yönteminin geleneksel yönteme göre daha çok katkı sağladığı görülmektedir. 
Özellikle hesaplanan eta-kare değerleri, grup ve öntest değişkenlerinin son test puanlarındaki değişkenliği önemli düzeyde açıklayabildiğini göstermektedir. Gruba ilişkin eta-kare değerinin yüksek bulunması, deneysel işlemin (yaratıcı drama yöntemi ile eğitimin) son test puanlarındaki değişkenliği önemli düzeyde açıklayabildiğini göstermektedir. Bu sonuçlar doğrultusunda, yaratıcı drama yöntemi ile verilen ilk yardım eğitiminin daha etkili olduğu görülmektedir. Aynı zamanda katılımcılarla ilgili geri bildirimlere ve gözlemlere göre, güvenlik kursunda verilen diğer derslerde de yaratıcı drama yönteminin kullanılması istenmiştir.

Çalışmadan elde edilen sonuçlara göre, güvenlik ve sürücü kurslarındaki diğer derslerde de yaratıcı drama yöntemine yer verilmesi, güvenlik elemanlarının hizmet içi eğitimlerinde de kullanılması, ilk yardım eğitimi verilen tüm kurslarda yaratıcı drama yöntemine yer verilmesi, eğitimcilere hizmet içi eğitim programlarında bu yöntemin uygulanmasına yönelik seminerler verilmesi ve daha iyi öğrenilmesi için atölye çalışmalarının yaygınlaştırılması önerilebilir.

\section{Kaynaklar}

Adıgüzel, Ö. (2006). Yaratıcı drama kavramı, bileşenleri ve aşamaları, Yaratıcı Drama Dergisi, 1, 1, $17-27$.

Adıgüzel, Ö. (2008). Türkiye'de eğitimde yaratıcı dramanın yakın tarihi, Yaratıcı Drama Dergisi, 1, 5, 7-28.

Akoğuz, M. (2002). İletişim becerilerinin geliştirilmesinde yaratıcı dramanın etkisi, Yayınlanmamış yüksek lisans tezi, Ankara: Ankara Üniversitesi.

Baykent, D. (2002). Fen bilimleri eğitiminde öğrenci motivasyonunu arttırma karakter eğitimine geçiş süreçleri, Yayınlanmamış yüksek lisans tezi, İstanbul: Marmara Üniversitesi.

Bıyık, T. (2001). İlköğretim okulları hayat bilgisi dersinde kullanılan dramatizasyon yönteminin etkinliği. Yayınlanmamış yüksek lisans tezi, Ankara: Gazi Üniversitesi.

Borg, W.R. and Gall, M. D. (Çeviren Köklü, N.) Değiş̧imin ölçülmesi, 133-140. Alınan adres: http:// dergiler.ankara.edu.tr/dergiler/40.484.5674.pdf. tarih 24.01.2011

Büyüköztürk, Ş. (2010) Sosyal Bilimler için Veri Analizi El Kitabı (12. bask1). Ankara: Pegem Akademi.

Büyüköztürk, Ş. (2007) Deneysel Desenler: Öntest-Sontest Kontrol Grubu Desen ve Veri Analizi (2.bask1). Ankara: Pegem A Yayınc1lık.

Çam, F., Özkan,E., ve Avinç, İ. (2009). Fen ve teknoloji dersinde drama yönteminin akademik başarı ve derse karşı ilgi açısından karşılaştırmalı olarak incelenmesi: Köy ve merkez okulları örneği, G.U. Gazi Ĕ̈itim Fakültesi Dergisi, 29, 2, 459-483.

Çebi, A. (2008). İlköğretim ikinci aşamada yaratıcı drama destekli bilgisayar okuryazarlığı, Akademik Bilişim 2008, Çanakkale Onsekiz Mart üniversitesi, Çanakkale, 30 Ocak-01 Şubat.

Doğan, M. (2004). Biyoloji derslerinde yaratıcı drama ile öğrenmeye örnekler, Ĕgitimde İyi Örnekler Konferansı, İstanbul, 17 Ocak.

Edwards, C. P. ve Springate, K. W. (1995). The lion comes out of the store: Helping young children achieve their creative potential, Dimensions of Early Childhood, 23, 4, 24-29.

Erdoğan, G. (2006). İlköğretim 8. sınıf (14-15 yaş) öğrencilerinin depresif belirti ve öz kavram 
düzeylerine yaratıcı drama çalışmalarının etkisi. Yayınlanmamış yüksek lisans tezi, Ankara: Gazi Üniversitesi.

Fullford, J., Hutchungs, M., Ross, A., ve Schmitz, U. (2001). İlköğretimde Drama. (Çev. Leyla Küçükahmet, Hande Borçbakan, S. Sadi Karamanoğlu). Ankara: Nobel Yayın Dağıtım.

Kara, Y. ve Çam, F. (2007). Yaratıcı drama yönteminin bazı sosyal becerilerin kazandırılmasına etkisi, Hacettepe Üniversitesi Ĕgitim Fakültesi Dergisi, 32, 145-155.

Nazik, B. (1997). 0-6 yaş çocuğu olan annelere verilen, ev kazalarında ilkyardım eğitimi modellerinin araştııılması. Yayınlanmamış doktora tezi, Ankara: Gazi Üniversitesi.

Nazik, B. (2003) İlkyardim. İstanbul: YA-PA Yayınc1lı.

O’Neil, C. ve Lambert, A. (1991). Drama Structures A Pratical Handbook for Teachers, Heironemen Educational Books. İngland: Inc. Chelpenman.

Oğur, B. ve Kılıç, G. B. (2004). Canlıların içyapısına yolculuk ve vücudumuzda neler var? Çevremizi nasıl alg1liyoruz? Ünitelerinde yaratıc1 drama uygulamas1, 6. Ulusal Fen Bilimleri ve Matematik Eğitimi Kongresi, İstanbul, 09-11 Eylül.

Ömeroğlu, E. (1990). Anaokuluna giden 5-6 yaşındaki çocukların sözel yaratıcılıklarının gelişiminde yaratıcı drama eğitiminin etkisi. Yayınlanmamış doktora tezi, Ankara: Hacettepe Üniversitesi.

Önalan Akfirat, F. (2006). Sosyal yeterlilik, sosyal beceri ve yaratıcı drama, Yaratıcı Drama Dergisi, 1, 1, 39-56.

Önder, A. (1999). Yaşayarak Öğrenme Iç̧in Ĕ̆itici Drama. İstanbul: Epsilon Yayıncılık.

Pinciotti, P.(1993). Creative drama and young children: The dramatic learning connection, Arts Education Policy Review, 94, 6, 1-24.

Sağırlı, H. (2001). İlköğretim 6. Sınıf fen bilgisi dersinde dramatizasyon yönteminin başarıya etkisi. Yayınlanmamış yüksek lisans tezi, İstanbul: Marmara Üniversitesi.

Sağırlı, H. E. ve Gürdal, A. (2002). Fen bilgisi dersinde drama tekniğinin öğrenci başarısına etkisi. $M$. Ü. Atatürk Eğitim Fakültesi Eğitim Bilimleri Dergisi, 15, 213-224.

Sağlam, T. (2004). Dramatik eğitim: Amaç mı? Araç mı?, A.U.D.T.C.F. Tiyatro Araştırmaları Dergisi, 17, 4-21.

San, İ. (1996). Yaratıcılı̆̆ı geliştiren bir yöntem ve yaratıcı bireyi yetiştiren bir disiplin: Eğitsel yaratıcı drama, Yeni Türkiye Dergisi, 7, 148-160.

San, İ.(1997). Drama, maske, müze, 6. Uluslararası Eğitimde Yaratıcı Drama Semineri, Ankara, Aralık 1997.

Selvi, K. (2003). Eğitimde yaratıcı drama yöntemini uygulama ilkeleri, Anadolu Üniversitesi, Ĕ̈itim Fakültesi Dergisi,13, 2, 181-188.

Susar Kırmızı, F. (2008). Türkçe öğretiminde yaratıcı drama yönteminin tutum ve okuduğunu anlama stratejileri üzerindeki etkisi, Pamukkale Üniversitesi Eğitim Fakültesi Dergisi, 23, 95-109.

Süzen, L.M. (2008). Temel Illkyardım. Ankara: BEDRAY Yayıncılık.

Tavşancıl, E. (2006) Tutumların Ölçülmesi ve SPSS ile Veri Analizi (3.bask1). Ankara: Nobel yayın.

Tekerek, N. (2007). Yaratıcı dramanın özgürlüğü, alışkanlıkların kalıpları ve bir uygulama örneği, Uludağ Üniversitesi Ĕ̆itim Fakültesi Dergisi xx, 1, 189-219.

Ulusoy Gökkoca, F.Z. (2001). Sağlık eğitimi açısından yetişkin eğitimi, sted 10, 11, 412-414. 
Üstündağ, T. (1996). Yaratıcı dramanın üç boyutu, Yaşadıkça Eğitim, 49, 19-23.

Üstündağ, T. (1998). Yaratıcı drama eğitim programının öğeleri, Eğitim ve Bilim, 22 (107), 28-35.

Üstündağ, T. (2006). Yaratıcı Drama Öğretmeninin Günlüğü, Ankara: Pegem Yayınc1lık.

Üstündağ, T. (2008). Polislerin hizmet içi eğitimi ve yaratıcı drama, Yaratıcı Drama Dergisi, 1, 5, 143150. 


\title{
Summary \\ The Effect of The Creative Drama About The Success of The Education in the First Aid
}

\author{
Behire SANÇAR* İnci AÇIKGÖZ** Ayşe Saba YALÇIN** \\ Ankara University
}

Drama, drama and drama techniques such as using improvisation and role-playing, an experience the participants in a group work, event, idea, training unit, a social concept, behavior, pattern of cognitive reorganization by the old observation, experience, feelings and experiences and review of playful processes (San1996, p.149).

Attendees to become creative drama method, dependency thinking, instead of being independent, can decide to bring, as well as social skills helps. It is important to develop skills in using the creativity of individuals in the process of creative drama (Önalan Akfırat, 2006, p.53).

Group of people who work with creative drama experiences, creative thinking, self-understanding, communication, problem solving, people become more sensitive, self-trust, gaining a sense of responsibility, the development of imagination, tolerance, increased social awareness, problem-solving ability, such as the development gains provides.

Individuals who participated in drama, in the process, states, events, relationships, exploring, learn by living. Acquisition of these experiences during the individual's verbal and nonverbal communication skills are developing (Üstündağ, 2006, p.27).

Research, drama activities offer extensive opportunities for creativity to put forward, in this way show that the individual's cognitive knowledge achieves higher levels.

In addition, the importance of drama in the router should not be ignored. Drama manager, provides the group dynamics, in some cases, timely intervention can change and new experiences can determine the flow.

Creative drama in the 1980s after the development of creative drama in education in Turkey, was born and is common in UK, USA, Canada, New Zealand and Germany, countries are coming to an important point in terms of (Adigüzel, 2008, p.27).

Creative Drama in Education, “a pre-written text, without the participants' own creative inventions, original thoughts, memories and information on the basis of subjective states of action and improvisation they create animations is defined as" (San, 1997, p.10).

(') Dr., Ankara Üniversitesi, Health Sciences Faculty, E-posta: bsancar@hotmail.com

(**)Dr., Ankara Üniversitesi, Health Sciences Faculty, E-posta: acikgoz@science.ankara.edu.tr

$\left(^{* *}\right)$ Dr., Ankara Üniversitesi, Health Sciences Faculty, ,E-posta: syalcin@health.ankara.edu.tr 
Of information gained through drama, not rote, social, emotional, discussing, exploring in an active way of learning. Information is used in the drama, but that person also puts his own feelings and thoughts of a permanent learning takes place. Therefore, education is important to use.

Health education, health, protection, development, treatment and rehabilitation of extremely important issues. Individuals, families, groups, organizations on the basis of the requirements include health education programs. First aid training in health education is very important in life.

First Aid, "any accident or a situation that endangered his life until to aid health officials, and rescue of life at the scene and instantly made the situation worse in order to prevent the non-drug interventions, defined as" (Nazik, 2003, p.7).

Accidents and life situations that endangered the measures needed to be done after coming to know and apply in these cases is also very important. Therefore, all segments of society, education must be given permanency. Based on the importance of this type of education, learning, living, creative drama method were asked to evaluate the impact on first-aid training. Area in the summer of this method in any study investigating the effect of first aid training has been found. Group processes acquired, determined persistence, this method is important in terms of self-expression are needed in all subjects. The method of creative drama with first-aid training, participants behave initially hesitant, but their confidence has increased towards the end of the drama through drama activities to co-operate, to express themselves in a group is beneficial socialize, have expressed what they have learned better. In order to determine the impact of creative drama, first aid training in case of electric shock, fractures, and the study participants tried to determine the effects of their methods of first aid applications. Participants learn first aid on the information and resources to identify applications, creative drama and traditional method to determine the effectiveness of the lower targets first-aid training took place.

The results obtained, the fractures caused by accidents and electric shock will help increase the awareness of people about these issues to contribute to decision-making method will be appropriate first-aid training and other studies will be considered will set an example.

The study, between July and August 2009 in Ankara, a special safety course and first aid course, the 100 participants were ongoing. The data, consisting of 34 questions prepared by the researchers of "creative drama method to investigate the effect of first aid training" by means of questionnaires were collected.The participants divided into two groups: the experimental and control groups.

Questionnaire to both groups at the beginning of the course before being given first aid course as a pre-test was applied.Using creative drama in a first aid course, the experimental group, while the control group with traditional training is given.

First-aid course at the end of the course participants as a final test re-administered the same questionnaire. Pretest-posttest scores in favor of the experimental and control groups significant differences were found between the experimental group. This result is given in the experimental group by using creative drama show that a more effective first-aid training.

Data, descriptive statistics, paired t-test (ANCOVA) was evaluated using the chi-square test using 
SPSS program. According to the findings of the groups found no significant difference between preand post test scores of both methods because it can be said to be effective on this training. However, the experimental group than the control group post-test scores increase in the average decrease in occurrence and standard deviation scores show the creative drama method is more effective than success. The application of first aid training at the end of the creative drama method is used in the experimental group between pre-and post-test achievement scores, according to conventional methods in training group found a statistically significant difference, post-test scores were high in the experimental group than the control group creative drama method is applied to permanent learning provide the method is connected to a positive change in behavior characteristics of permanency on the participants. At the same time the feedback and observations taken on the issue, according to the security of the other courses in the course were asked to use creative drama method. According to the results of first aid training courses in driver safety courses and other courses to be included in the method of creative drama, using this method in-service training of security staff, educators, creative drama method for the implementation of in-service training programs, seminars given, all the first aid training courses, creative drama. Using this method, all the lessons needed to learn better suggestions were made relating to extension of the workshops. 
